\title{
VIGOR TESTS ASSOCIATION AS AN ALTERNATIVE FOR PRECISE AND EFFICIENT ASSESSMENT OF MAIZE SEED QUALITY ${ }^{1}$
}

\author{
MARCOS ALTOMANI NEVES DIAS ${ }^{2}$, VITOR HENRIQUE VAZ MONDO*³ ${ }^{3}$ SILVIO MOURE CICERO ${ }^{2}$, NAYARA \\ ROBERTO GONÇALVES ${ }^{2}$, CIBELE APARECIDA TEIXEIRA DA SILVA ${ }^{2}$
}

\begin{abstract}
This study aimed to associate two concepts of seed vigor testing, the aging and seedling growth using image analysis, providing a feasible and time-saving way to evaluate maize seed vigor in large scale. For this purpose, five seed lots with different vigor levels from two single hybrids were used. The seeds were characterized by moisture content, germination, seedling emergence, seedling emergence speed index, accelerated aging and cold tests. The treatments were composed by varying the accelerated aging periods $(0,24,48,72$ and $96 \mathrm{~h}$ ) and seedling growth periods (48 and $72 \mathrm{~h}$ ), before submitting the seedlings to image analysis for seedling root length measurement. Considering the results obtained, the adaptation of accelerated aging test by reducing the aging duration from $96 \mathrm{~h}$ to $48 \mathrm{~h}$, and the replacement of the germination test by seedling root length measurement using image analysis could be considered a potential tool for maize seed vigor assessment. The treatments composed of $48 \mathrm{~h}$ of seed aging followed by seedlings root length measurements using image analysis provided reliable data, compared to traditional vigor tests and it could be considered an efficient and timesaving approach, associating two different concepts of seed vigor analysis.
\end{abstract}

Keywords: Zea mays L. Seed analysis. Physiological potential. Image analysis.

\section{ASSOCIAÇÃO DE TESTES DE VIGOR PARA AVALIAÇÃO PRECISA E EFICIENTE DA QUALIDADE DE SEMENTES DE MILHO}

RESUMO - O experimento teve como objetivo associar conceitos para avaliação do vigor de sementes, o envelhecimento acelerado e crescimento de plântulas medido por meio da análise de imagens. Para tanto, cinco lotes de sementes com diferentes níveis de vigor de dois híbridos simples foram utilizados. As sementes foram caracterizadas pelo teor de água, germinação, porcentagem e índice de velocidade de emergência de plântulas, envelhecimento acelerado e teste de frio. Os tratamentos foram constituídos por diferentes períodos de envelhecimento acelerado $(0,24,48,72$ e $96 \mathrm{~h})$ e de crescimento de plântulas (48 e 72h) e, em seguida, as plântulas, submetidas à análise de imagens para mensuração do comprimento de raízes. A adaptação do teste de envelhecimento acelerado, reduzindo a duração do envelhecimento de $96 \mathrm{~h}$ para $48 \mathrm{~h}$ e a substituição do teste de germinação pela mensuração do comprimento de raízes das plântulas por meio da análise de imagens, comprovou-se um método potencial para avaliação da qualidade de sementes de milho. Assim, os tratamentos compostos por 48h de envelhecimento, seguido pela mensuração do comprimento de raízes utilizando a análise de imagens, forneceram dados confiáveis em comparação aos testes de vigor tradicionais e podem ser considerados uma nova abordagem para a análise de vigor de sementes.

Palavras-chave: Zea mays L. Análise de sementes. Potencial fisiológico. Análise de imagens.

\footnotetext{
*Corresponding author

${ }^{1}$ Received for publication in 29/08/2014; accepted in 23/02/2015.

${ }^{2}$ University of São Paulo, Escola Superior de Agricultura 'Luiz de Queiroz' (USP/ESALQ) - Crop Science Department, PO Box 09, 13418-900, Piracicaba-SP, Brazil; marcosaltomani@hotmail.com.

${ }^{3}$ Embrapa Rice and Beans - GO-462 - Km 12 - Zona Rural - 75375-000 - Santo Antônio de Goiás-GO, Brazil; vitor.mondo@embrapa.br.
} 


\section{INTRODUCTION}

The maize seed industries are recognized for dealing with cutting-edge technologies, on a global scale. In Brazil, the presence of multinationals companies brought large investments in research and development to this sector, which has changed the scenario by improving the quality of maize seeds available to growers. In these companies, many segments work jointly, in order to produce the best quality seeds, in terms of genetics and physiological potential. The last phase, previous to seed release in the market, is the quality assurance, which is crucial to guarantee the seed quality standards.

Several years of research were dedicated to develop vigor tests, which are successfully used either by seed companies on seed quality control programs or to research purposes, providing information about the planting value of a wide range of environmental conditions and evaluate storage potential of seed lots (HAMPTON; TEKRONY, 1995), as well as additional information to differentiate seed lots of acceptable standard germination (TEKRONY, 2003; VIEIRA et al, 2004).

The deterioration during storage of commercial seeds could be defined as one of the main causes of seed quality losses. According to this fact, the accelerated aging test (MCDONALD; PHANNENDRANATH, 1978) was developed based on the concept of tolerance to stresses as high temperature and relative humidity, and could be well correlated with storage potential for seeds of many species. The test is conducted in eight days for maize (MARCOSFILHO, 1999; DUTRA; VIEIRA, 2004) and it could be considered longstanding to be included in seed quality control programs, where the ability to obtain quick results has many advantages, mainly, allowing quick decision-making.

As the seed quality control is time and cost spending, improvements towards reducing both parameters are highly desirable. Moreover, with increases of seeds produced and the competitiveness in the maize seed market, there is a need for more efficiency in all process related to seed production.

There is considerable interest in developing methods and equipment that enable a rapid and automated evaluation of seed quality (VAN DER BURG, 2009) and, despite the reliability of available seed vigor tests, there are still opportunities to improve or develop new methods (MARCOS-FILHO et al., 2009). Considering this, the seedling image analysis is a relatively new approach for seed vigor testing purposes, bringing many advantages, as the avoidance of human error, precise data and greater flexibility in the evaluations, and it had been well described for maize seed evaluations (HOFFMASTER et al., 2005; OTONI; MCDONALD, 2005; GOMESJUNIOR et al., 2009; MONDO et al., 2011).

In addition to that, the inclusion of seedling growth analysis after seed accelerated aging may enable a more detailed evaluation of a given seed lot, which could enrich the data obtained when compared to the traditional, accelerated aging test. Thus, this study aimed to associate two concepts of seed vigor testing, aging and seedling growth, providing a feasible and time-saving way to evaluate maize seed vigor in large scale.

\section{MATERIAL AND METHODS}

Maize seeds from single hybrids 'Dow 2A120' and 'BR206', provided by the seed companies Dow AgroSciences and Riber KWS, respectively, were used for this study. Each hybrid was represented by five seed lots, uniform in seed size and different in terms of physiological potential. The following tests were carried out for seed lot characterization.

Moisture content (MC): determined by oven drying two seed samples of $20 \mathrm{~g}$ from each seed lot at $105^{\circ} \mathrm{C} \pm 3^{\circ} \mathrm{C}$ for 24 hours, followed by weighing (BRASIL, 2009). The results were expressed as percentage.

Germination $(\mathrm{G})$ : carried out with four replicates of 50 seeds per lot in rolled paper towels. Seeds were uniformly distributed on two germination paper towels moistened with water to 2.5 times the dry paper weight and covered with another paper towel. The rolls were vertically placed in a dark germination chamber at $25 \pm 1{ }^{\circ} \mathrm{C}$. The percentage of normal seedlings was recorded on the seventh day after sowing (BRASIL, 2009).

Seedling emergence (SE) and seedling emergence speed index (SESI):conducted with four replicates of 50 seeds per lot, uniformly distributed in plastic boxes $(47 \times 30 \times 11 \mathrm{~cm})$ filled with sand, moistened with $60 \%$ of the water holding capacity and maintained at room temperature $\left(25^{\circ} \mathrm{C}\right)$. The emerged seedlings were counted daily, considering only seedlings with coleoptiles at least $1 \mathrm{~cm}$ above the substrate surface, for calculating the SESI (MAGUIRE, 1962). The final counting occurred at the seventh day, and the results were expressed as a percentage of emerged seedlings.

Cold test (CT): conducted with four replicates of 50 seeds per lot, uniformly distributed in plastic boxes $(47 \times 30 \times 11 \mathrm{~cm})$ filled with a soil-sand mixture $(25-75 \%)$, moistened with $60 \%$ of water holding capacity. After sowing, the boxes were maintained in a chamber at $10^{\circ} \mathrm{C}$ for seven days and then placed at room temperature $\left(25^{\circ} \mathrm{C}\right)$. Afterward, the total emerged seedlings, considering only seedlings with coleoptiles at least $1 \mathrm{~cm}$ above the substrate surface, were counted on the fifth day, and the results were expressed as a percentage of emerged seedlings.

Accelerated aging (AA): performed with four replicates of 50 seeds per lot. The seeds were placed on a screen inside transparent plastic boxes $(11.5 \mathrm{x}$ $11.5 \times 3.5 \mathrm{~cm})$ and suspended over $40 \mathrm{~mL}$ of water. 
The boxes were placed in a germination chamber and maintained at $41 \pm 1^{\circ} \mathrm{C}$ for $96 \mathrm{~h}$ (MONDO; CICERO, 2005). After the aging period, seeds were submitted to the germination test, as described previously, and the normal seedlings were counted on the $4^{\text {th }}$ day after sowing. The results were expressed as a percentage of normal seedlings.

The treatments were composed by varying the accelerated aging (AA) and seedling growth periods, followed by seedling root length evaluation through image analysis. For determining the efficiency of AA combined with Seedling Root Length analysis (SRL), the treatments proposed were based on five aging periods $(0,24,48,72$ and $96 \mathrm{~h})$ and two seedling growth periods (48 and $72 \mathrm{~h}$, two and three-dayold seedlings, respectively). The AA tests were conducted using the same methodology described previously, with variations in aging and seedling growth periods.

The seedling growth tests were carried out under the same conditions of germination test previously described, with three replicates of 25 seeds, in order to avoid contact with seedlings, and the seeds were positioned with radicle end pointed downwards, in order to standardize root growth conditions for all samples. For seedling root length evaluation, at the second and third days after germination test installation, the seedlings images from each treatment were obtained from an inverted scanner (Scanjet HP) with 100 dpi resolution, and the images processed by the software Seed Vigor Imaging System (SVIS ${ }^{\mathrm{TM}}$ ) by measuring the length of the primary root, in millimeters.

The data was submitted to analysis of variance in a completely randomized design and in case of significance according to the $\mathrm{F}$ values, means were compared using Tukey's test $(p \leq 0,05)$.

\section{RESULTS AND DISCUSSION}

Initial moisture content varied from 7.5 to $7.6 \%$ for hybrid Dow $2 \mathrm{~A} 120$ and from 9.4 to $10.7 \%$ for hybrid BR206, which were considered acceptable values, indicating that this parameter have not influenced seed lot performance on potential physiological tests. Also, it is important to highlight that the seed moisture content after aging, independent of aging duration, varied less than two percent points among samples, emphasizing a proper conduction of the seed aging test.

The physiological potential characterization (Table 1) showed similar germination among seed lots, for both hybrids. This result is a premise for this kind of study, where seed lots must differ only in terms of seed vigor, and be similar to germination percentages. The results also pointed to similarity among seed lots for seedling emergence, which was expected, considering the stable conditions of temperature and moisture used for this test. According to Egli and Rucker (2012), seed lots with the same standard germination but a range in vigor levels will often produce equal emergence in ideal field conditions, but the high vigor lots will have an advantage when conditions are less than ideal. Considering this statement, the cold test, seedling emergence speed index and accelerated aging test, which are considered well standardized assessments, segregated lots 1 and 2 as high vigor, lot 3 as intermediate vigor and lots 4 and 5 as low vigor for hybrid 2A120. Those tests could also segregate the seed lots from hybrid BR206, being lots 1, 2 and 3 segregated as high vigor and lots 4 and 5 as low vigor.

The planting quality is normally characterized by the germination test, which measures the ability of a seed lot to produce normal seedlings under optimal conditions for the considered specie (AOSA, 2005). On the other hand, predicting the seed lot performance under suboptimal field conditions is the main goal of seed vigor tests (TEKRONY et al., 1987). In this scenario, the accelerated aging test is considered one of the most sensitive and efficient vigor test for various species (MARCOS-FILHO, 2005).

In Tables 2, 3, 4 and 5, the results were provided by the association of two vigor tests, accelerated aging and seedling root length, measured by image analysis with the software SVISTM. This software enabled a rapid assessment of seedling development.

For hybrid $2 \mathrm{~A} 120$, with seedling root length measured after two days (Table 2), it is possible to observe that the $48 \mathrm{~h}$ AA treatment segregated the seed lots equally to the $96 \mathrm{~h}$ AA treatment, which can be considered a good result, by reducing the time spent on seed aging and, consequently, the whole test from eight to four days. Those tests could segregate lots one to five very close to the other standardized vigor tests. For the procedure using three-dayold seedlings (Table 3 ), the treatments with 24 and 96h AA resulted in the same segregation found for two-day-old seedlings. It is expected that a reduction in seed aging duration can be compensated by the seedling growth analysis, which is also used for seed vigor assessment. On the other hand, the germination test is not able to provide data related to seed vigor. As an example of this compensatory effect, the $48 \mathrm{~h}$ AA with two-day-old seedlings and $24 \mathrm{~h} \mathrm{AA}$ with three-day-old seedlings similarly segregated seed lots. 
Table 1. Maize seed lots physiological potential characterization. G - Germination; CT - Cold test; SE - Seedling emergence; SESI - Seedling emergence speed index; AA - Accelerated aging.

\begin{tabular}{|c|c|c|c|c|c|c|}
\hline Hybrid & Seed lot & $\mathrm{G}(\%)$ & CT (\%) & SE (\%) & SESI & AA $(\%)$ \\
\hline \multirow{6}{*}{$2 \mathrm{~A} 120$} & 1 & $97 a^{*}$ & $92 \mathrm{a}$ & $98 \mathrm{a}$ & $23.0 \mathrm{a}$ & $86 \mathrm{a}$ \\
\hline & 2 & $95 \mathrm{a}$ & $86 \mathrm{a}$ & $97 \mathrm{a}$ & $22.7 \mathrm{ab}$ & $74 \mathrm{a}$ \\
\hline & 3 & $95 \mathrm{a}$ & $72 b$ & $95 \mathrm{a}$ & $22.2 \mathrm{ab}$ & $56 \mathrm{~b}$ \\
\hline & 4 & $90 \mathrm{a}$ & $58 \mathrm{c}$ & $95 \mathrm{a}$ & $21.1 \mathrm{ab}$ & $35 \mathrm{c}$ \\
\hline & 5 & $90 \mathrm{a}$ & $54 \mathrm{c}$ & $95 \mathrm{a}$ & $19.8 \mathrm{~b}$ & $18 \mathrm{~d}$ \\
\hline & CV (\%) & 3.90 & 5.70 & 4.70 & 6.40 & 13.30 \\
\hline \multirow{6}{*}{ BR206 } & 1 & $92 \mathrm{a}$ & $71 \mathrm{a}$ & $88 \mathrm{a}$ & $18.6 \mathrm{a}$ & $78 \mathrm{a}$ \\
\hline & 2 & $88 \mathrm{a}$ & $63 a b$ & $84 \mathrm{a}$ & $17.2 \mathrm{ab}$ & $76 a$ \\
\hline & 3 & $86 \mathrm{a}$ & $63 a b$ & $77 \mathrm{a}$ & $14.9 \mathrm{ab}$ & $71 \mathrm{ab}$ \\
\hline & 4 & $84 \mathrm{a}$ & $61 \mathrm{ab}$ & $76 a$ & $14.7 \mathrm{~b}$ & $68 \mathrm{~b}$ \\
\hline & 5 & $81 \mathrm{a}$ & $53 \mathrm{~b}$ & $72 \mathrm{a}$ & $14.4 \mathrm{~b}$ & $54.5 \mathrm{~b}$ \\
\hline & CV (\%) & 6.50 & 12.50 & 9.20 & 11.30 & 11.70 \\
\hline
\end{tabular}

*Means followed by same letter in the column do not significantly differ according to Turkey's test $(\mathrm{p}<0.05)$. CV: coefficient of variance.

Table 2. Maize Hybrid 2A120 two-day-old seedlings root length, in millimeters, evaluated with seed vigor imaging system.

\begin{tabular}{cccccc}
\hline \multirow{2}{*}{ Seed lot } & \multicolumn{5}{c}{ Two-day-old seedlings } \\
\cline { 2 - 5 } & $0 \mathrm{~h}$ & $24 \mathrm{~h}$ & $48 \mathrm{~h}$ & $72 \mathrm{~h}$ & $96 \mathrm{~h}$ \\
\hline 1 & $26.05 \mathrm{a}^{*}$ & $15.87 \mathrm{a}$ & $17.22 \mathrm{a}$ & $7.39 \mathrm{~b}$ & $11.74 \mathrm{a}$ \\
2 & $21.80 \mathrm{~b}$ & $13.76 \mathrm{a}$ & $11.53 \mathrm{ab}$ & $15.73 \mathrm{a}$ & $7.45 \mathrm{ab}$ \\
3 & $21.39 \mathrm{~b}$ & $9.14 \mathrm{~b}$ & $5.65 \mathrm{bc}$ & $5.74 \mathrm{bc}$ & $3.65 \mathrm{bc}$ \\
4 & $15.10 \mathrm{c}$ & $6.57 \mathrm{~b}$ & $4.50 \mathrm{c}$ & $4.29 \mathrm{bc}$ & $0.99 \mathrm{c}$ \\
\hline $\mathrm{CV}(\%)$ & $10.88 \mathrm{~d}$ & $4.67 \mathrm{~b}$ & $1.24 \mathrm{c}$ & $0.47 \mathrm{c}$ & $0.00 \mathrm{c}$ \\
\hline
\end{tabular}

*Means followed by same letter in the column do not significantly differ according to Turkey's test $(\mathrm{p}<0.05)$. CV: coefficient of variance.

For hybrid BR206, data is presented in Tables 4 and 5 . It was possible to observe in this case that the 24h AA treatment associated with two-day-old seedlings (Table 4) could segregate seed lots as well as the cold test, and the $48 \mathrm{~h} \mathrm{AA}$ treatment similarly to accelerated aging test (Table 1). On the other hand, for the three-day-old seedlings analysis (Table
5), the 24h AA treatment wasn't able to segregate the seed lots, thus pointing to the demand of a longer period destined for seed aging. In this case, the $48 \mathrm{~h}$ AA treatment showed to be more appropriate to segregate seed lots closely to vigor tests used in physiological potential characterization (Table 1). 
M. A. N. DIAS et al.

Table 3. Maize Hybrid 2A120 three-day-old seedlings root length ( $\mathrm{mm})$, evaluated with seed vigor imaging system.

\begin{tabular}{cccccc}
\hline \multirow{2}{*}{ Seed lot } & \multicolumn{5}{c}{ Three-day-old seedlings } \\
\cline { 2 - 6 } & $0 \mathrm{~h}$ & $24 \mathrm{~h}$ & $48 \mathrm{~h}$ & $72 \mathrm{~h}$ & $96 \mathrm{~h}$ \\
\hline 1 & $80.44 \mathrm{a}^{*}$ & $55.31 \mathrm{a}$ & $58.31 \mathrm{a}$ & $43.23 \mathrm{a}$ & $33.08 \mathrm{a}$ \\
2 & $77.39 \mathrm{a}$ & $48.82 \mathrm{ab}$ & $43.46 \mathrm{ab}$ & $51.79 \mathrm{a}$ & $20.83 \mathrm{ab}$ \\
3 & $63.66 \mathrm{~b}$ & $31.53 \mathrm{bc}$ & $34.63 \mathrm{~b}$ & $18.54 \mathrm{~b}$ & $9.31 \mathrm{bc}$ \\
4 & $54.91 \mathrm{bc}$ & $27.54 \mathrm{c}$ & $27.85 \mathrm{bc}$ & $17.68 \mathrm{~b}$ & $5.45 \mathrm{c}$ \\
5 & $46.09 \mathrm{c}$ & $23.32 \mathrm{c}$ & $10.44 \mathrm{c}$ & $6.73 \mathrm{~b}$ & $0.55 \mathrm{c}$ \\
\hline $\mathrm{CV}(\%)$ & 6.83 & 16.64 & 18.35 & 19.96 & 37.59 \\
\hline
\end{tabular}

* Means followed by same letter in the column do not significantly differ according to Turkey's test (p $<0.05)$. CV: coefficient of variance.

Table 4. Maize Hybrid BR206 two-day-old seedlings root length (mm), evaluated with seed vigor imaging system.

\begin{tabular}{cccccc}
\hline \multirow{2}{*}{ Seed lot } & \multicolumn{4}{c}{ Two-day-old seedlings } \\
\cline { 2 - 5 } & $0 \mathrm{~h}$ & $24 \mathrm{~h}$ & $48 \mathrm{~h}$ & $72 \mathrm{~h}$ & $96 \mathrm{~h}$ \\
\hline 1 & $25.50 \mathrm{a}^{*}$ & $15.01 \mathrm{a}$ & $19.01 \mathrm{a}$ & $30.54 \mathrm{a}$ & $15.79 \mathrm{a}$ \\
2 & $19.51 \mathrm{ab}$ & $14.32 \mathrm{ab}$ & $18.39 \mathrm{a}$ & $22.37 \mathrm{a}$ & $17.47 \mathrm{a}$ \\
3 & $17.64 \mathrm{bc}$ & $13.43 \mathrm{ab}$ & $13.83 \mathrm{ab}$ & $20.79 \mathrm{a}$ & $15.41 \mathrm{ab}$ \\
4 & $15.71 \mathrm{bc}$ & $12.07 \mathrm{ab}$ & $10.43 \mathrm{~b}$ & $20.74 \mathrm{a}$ & $7.15 \mathrm{bc}$ \\
5 & $11.98 \mathrm{c}$ & $7.43 \mathrm{~b}$ & $8.13 \mathrm{~b}$ & $10.07 \mathrm{~b}$ & $7.72 \mathrm{c}$ \\
\hline $\mathrm{CV}(\%)$ & 13.00 & 20.04 & 14.78 & 17.15 & 22.34 \\
\hline
\end{tabular}

*Means followed by same letter in the column do not significantly differ according to Turkey's test $(\mathrm{p}<0.05)$. CV: coefficient of variance.

The primary root emergence and, consequently, root growth, usually is delayed from deteriorated seeds; evidence suggests that the extent of deterioration determines the length of the delay, during which metabolic repair of damage caused by deterioration takes place before further germination processes can continue (MATTHEW et al., 2012). Also, Hochholdinger et al. (2004) affirmed that on grass species, the SRL is a good way to estimate seed vigor. Those facts confirm SRL as a potential method to be used, with the aim of reducing time and costs of seed lot quality assessment.

Table 5. Maize Hybrid BR206 three-day-old seedlings root length ( $\mathrm{mm}$ ), evaluated with seed vigor imaging system.

\begin{tabular}{cccccc}
\hline \multirow{2}{*}{ Seed lot } & \multicolumn{5}{c}{ Three-day-old seedlings } \\
\cline { 2 - 5 } & $0 \mathrm{~h}$ & $24 \mathrm{~h}$ & $48 \mathrm{~h}$ & $72 \mathrm{~h}$ & $96 \mathrm{~h}$ \\
\hline 1 & $57.41^{\mathrm{ns}}$ & $41.14^{\mathrm{ns}}$ & $59.70 \mathrm{a}^{*}$ & $52.97 \mathrm{ab}$ & $50.39 \mathrm{a}$ \\
2 & 53,29 & 40,37 & $52.86 \mathrm{ab}$ & $60.29 \mathrm{a}$ & $48.81 \mathrm{a}$ \\
3 & 48,12 & 40,55 & $47.25 \mathrm{ab}$ & $47.47 \mathrm{~b}$ & $46.93 \mathrm{a}$ \\
4 & 48,66 & 34,14 & $39.00 \mathrm{ab}$ & $40.34 \mathrm{bc}$ & $34.77 \mathrm{ab}$ \\
5 & 45,67 & 26,74 & $35.57 \mathrm{~b}$ & $31.89 \mathrm{c}$ & $28.65 \mathrm{~b}$ \\
\hline $\mathrm{CV}(\%)$ & 8.58 & 17.87 & 18.64 & 9.66 & 13.51 \\
\hline
\end{tabular}

*Means followed by same letter in the column do not significantly differ according to Tukey's test $(\mathrm{p}<0.05)$. ${ }^{\text {ns }}$ Nonsignificant by $F$ test $(\mathrm{P}<0.05)$. $C V$ : coefficient of variance. 
Seed vigor tests are based on different concepts, such as the resistance to stress, as CT and AA, speed of germination, as SESI, membrane integrity, as electrical conductivity (EC) and seedling development, as SRL (MATTHEWS et al., 2012) and its association with the pursuit of efficiency, fastness and cost reduction on seed analysis has been tried in few opportunities in literature. One example is the application of AA test associated with tetrazolium test (TT), which was studied by Bittencourt et al. (2012) on maize seeds. The authors found that the combination of both vigor tests resulted in similar results compared to the traditional method of AA test, which could lead to time-saving during a seed analysis routine in laboratories.

Considering the results obtained in the present research work, the adaptation of AA test by reducing the aging duration from $96 \mathrm{~h}$ to $48 \mathrm{~h}$, and the replacement of the germination test by seedling root length measurement using image analysis could be considered a potential method for maize seed vigor analysis. In general, it reduces the test total duration from eight days, or $192 \mathrm{~h}$, to four days, or $96 \mathrm{~h}$, which represents approximately $50 \%$ of time reduction. Additionally it brings to test the benefits of image analysis, with reproducible results, practical procedures and does not involving human error in count evaluations, estimates and measurements (SAKO et al., 2001; HOFFMASTER et al., 2003; HOFFAMSTER et al., 2005 ).According to Barros and Marcos -Filho (1997), Pinto et al. (2007) and Santorum et al. (2013), there is an increasing need for efficient methods to assess the physiological quality of seeds, which enable decision making regarding the collection, processing, storage and marketing of the crop, and the association of AA and SRL tests could be a great alternative to meet those demands.

\section{CONCLUSION}

The treatments composed of $48 \mathrm{~h}$ of seed aging followed by seedlings root length measurement using image analysis provide reliable data, compared to traditional vigor tests and it could be considered an efficient and time-saving approach for maize seed vigor assessment. Moreover, by associating two different concepts of seed quality analysis, accelerated aging and seedling root length, the test can provide more consistent data referring to seed vigor.

\section{REFERENCES}

ASSOCIATION OF OFFICIAL SEED ANALYSTS - AOSA. Rules for testing seeds. AOSA, Las Cruces, NM. 2005.

BRASIL. Ministério da Agricultura, Pecuária e
Abastecimento. Regras para análise de sementes. Brasília: MAPA/ACS, 2009. 399 p.

BARROS, A. S. R.; MARCOS-FILHO, J. Testes para avaliação rápida do vigor de sementes de soja. Journal of Seed Science, Pelotas, v. 19, n. 2, p. 288 294, 1997.

BITTENCOURT, S. R. M. et al. Alternative methodology for the accelerated aging test for corn seeds. Ciência Rural, Santa Maria, v. 42, n. 8, p. 13601365, 2012.

DUTRA, A. S.; VIEIRA, R. D. Accelerated aging as test of vigor for corn and soybean seeds. Ciência Rural, Santa Maria, v. 34, n. 3, p. 715-721, 2004.

EGLI, D.B.; RUCKER, M. Seed vigor and the uniformity of emergence of corn seedlings. Crop Science, Madison, v. 52, n. 6, p. 2774-2782, 2012.

GOMES-JUNIOR, F. G. et al. Evaluation of priming effects on sweet corn seeds by SVIS. Seed Technology Journal, Washington, v. 33, n. 1, p. 95-100, 2009

HAMPTON, J. G.; TEKRONY, D. M. Handbook of vigour test methods, $3^{\text {rd }}$ ed. International Seed Testing Association, Zurick, Switzerland. 1995. 117 p.

HOCHHOLDINGER, F. et al. From weeds to crops: genetic analysis of root development in cereals. Trends in Plant Science, Cambridge, v. 9, n. 1, p. 42-48, 2004.

HOOFMASTER, A. L. et al. An automated system for vigor testing three-day-old soybean seedlings. Seed Science and Technology, Bassersdorf, v. 31, n. 3, p. 701-713, 2003.

HOFFMASTER, A. L. et al. Seed Vigor Imaging System (SVIS) for soybean and corn seedlings. Seed Technology Journal, Washington, v. 27, n. 1, p. 723, 2005.

MAGUIRE, J. D. Speed of germination aid in selection and evaluation for seedling emergence and vigor. Crop Science, Madison, v. 2, n. 2, p. 176-177, 1962.

MARCOS-FILHO, J. Testes de vigor: importância e utilização. In: KRZYZANOWSKI, F. C.; VIEIRA, R. D.; FRANÇA NETO, J. B. (Ed.). Vigor de sementes: conceitos e testes. Londrina: Abrates, 1999. p. 1-21.

MARCOS-FILHO, J.; KIKUTI, A. L. P.; LIMA, L. B. Procedures for evaluation of soybean seed vigour, including an automated computer imaging system. Journal of Seed Science, Londrina, v. 31, n. 1, p. 
$102-112,2009$.

MARCOS-FILHO, J. Fisiologia de sementes de plantas cultivadas. Piracicaba: Fealq, 2005. 495 p.

MATTHEWS, S. et al. Evaluation of seed quality: from physiology to international standardization. Seed Science Research, Cambridge, v. 22, Supplement S1, p. 69-73, 2012.

MCDONALD, M. B.; PHANNENDRANATH, B. R. A modified accelerated aging vigor test procedure. Seed Technology Journal, Washington, v. 3, n. 1, p. 27-37, 1978.

MONDO, V. H. V.; CICERO, S. M. Using image analysis to evaluate the quality of maize seeds located in different positions on the ear. Journal of Seed Science, Pelotas, v. 27, n. 1, p. 9-18, 2005.

MONDO, V. H. V.; DIAS, M. A. N.; CICERO, S. $M$. Seed vigor imaging system for two-day-old corn seedling evaluation. Seed Technology Journal, Washington, v. 33, n. 2, p. 191-196, 2011.

OTONI, R. R.; MCDONALD, M. B. Moisture and temperature effects on maize and soybean seedlings using the seed vigor imaging system. Seed Technology Journal, Washington, v. 27, n. 2, p. 243-247, 2005.

PINTO, T. L. F.; CICERO, S. M.; FORTI, V. A. Image analysis technique to evaluate weathering damage in soybean seeds. Journal of Seed Science, Londrina, v. 29, n. 3, p. 31-38, 2007.

SAKO, Y. et al. A system for automated seed vigour assessment. Seed Science and Technology, Bassersdorf, v. 29, n. 3, p. 625-636, 2001.

SANTORUM, M. et al. Comparison of test for the analysis of vigor and viability in soybean seeds and their relationship to field emergence. Acta Scientiarum, Maringá, v. 35, n. 1, p. 83-92, 2013.

TEKRONY, D. M.; EGLI, D. B.; WHITE, G. M. Seed production and Technology. In: WILCOX, J. R. (ed.). Soybeans: Improvement, production and uses. $2^{\text {nd }}$ ed. Agron. Monogr.16. ASA, CSSA, and SSSA. Madison, WI. p. 295-353, 1987.

TEKRONY, D. M. Precision is an essential component in seed vigor testing. Seed Science and Technology, Bassersdorf, v. 31, n. 2, p. 435-447, 2003.

VAN DER BURG, J. Raising seed quality: what is in the pipeline? Proceedings of the $2^{\text {nd }}$ World Seed Conference. FAO, Rome, v. 1, n. 1, p. 177-185, 2009.
VIEIRA, R. D. et al. Electrical conductivity of seed soaking solution and soybean seedling emergence. Scientia Agricola, Piracicaba, v. 61, n. 2, p. 164$168,2004$. 